\title{
Importance of Genetic Engineering and Gene Therapy in the Management of Viral Diseases and Outbreaks
}

\author{
Vanshika Arora ${ }^{1}$, Ashim Aggarwal2 ${ }^{2}$, Shivani Aggarwal ${ }^{3}$, Randhir Kumar ${ }^{4}$ \\ ${ }^{1}$ Manav Rachna Dental College, Manav Rachna International Institute of Research and Studies, Faridabad, Haryana, \\ India. ${ }^{2}$ Department of Oral \& Maxillofacial Surgery, Manav Rachna Dental College, Manav Rachna International \\ Institute of Research and Studies Faridabad, Haryana, India. ${ }^{3}$ Department of Oral Pathology \& Microbiology, Manav \\ Rachna Dental College, Manav Rachna International Institute of Research and Studies Faridabad, Haryana, India. \\ ${ }^{4}$ Department of Periodontology, Patna Dental College and Hospital, Patna, Bihar, India.
}

\section{ABSTRACT}

\section{BACKGROUND}

Emerging globalisation over the years has brought a lot of opportunities in every corner of the world. The economy is now evolving, and things are getting easier for the public. But with all these affirmations, the spread of diseases all around the world has become easier and harder to contain. Epidemics usually result in pandemics due to the constant movement of the people from one part of the world to other. With the recent rapid onset of the COVID-19 pandemic, the world has come to realise the inadvertent and unequal nature of the severity, and spread in the region of the disease. Hence, it is fair to say that such outbreaks carry the potential to cause a catastrophe on the global economy and livelihood. A changing environment and landscape, as we know, can cater to the fitness and development of new and accomplished viral diseases, and in today's era, with factors such as increasing population, tropical deforestation and rapid industrialisation, the viruses tend to adapt and exploit the replication of their genomes. Hence, leading to severe conditions in the human body. Some of the notable viral outbreaks include severe acute respiratory syndrome (SARS), HIV-AIDS, Ebola and the ongoing COVID-19. Genetic therapy is an extensively specific and elaborate stream which deals with manipulation of the human genes and is being considered as a form of a promising alternate medicine. The management of infectious diseases demands the introduction of specifically designed genes to either inhibit or block the gene expression to manoeuvre the functioning of the infectious agents. The following review discusses some of the most recent and notable outbreaks, their symptoms and the how advancements in genetic therapy came into play in treating, nullifying and managing them along with the rationale of the prospects and problems faced by the scientists over the years in developing vaccinations, treatment modalities and new controlled procedures in regulations of such outbreaks all over the world.

\section{KEY WORDS}

Pandemic, Genetic Engineering, Molecular Therapy, Immunotherapy, Reverse Genetics, RNA Decoys, HIV-AIDS, Ebola Virus, SARS, H1N1 Influenza, COVID-19
Corresponding Author: Dr. Shivani Aggarwal, W-15/2, Western Avenue, Sainik Farms - 110062, New Delhi, India.

E-mail: shivaniashim@gmail.com

DOI: $10.14260 /$ jemds/2021/80

How to Cite This Article:

Arora V, Aggarwal A, Aggarwal S, et al. Importance of genetic engineering and gene therapy in the management of viral diseases and outbreaks. J Evolution Med Dent Sci 2021;10(06):357-361, DOI: $10.14260 / \mathrm{jemds} / 2021 / 80$

Submission 02-10-2020,

Peer Review 13-12-2020,

Acceptance 18-12-2020,

Published 08-02-2021.

Copyright (C) 2021 Vanshika Arora et al. This is an open access article distributed under Creative Commons Attribution License [Attribution 4.0 International (CC BY 4.0)] 


\section{BACKGROUND}

$21^{\text {st }}$ century has seen a lot of development in terms of economy, healthcare, trade and other services. The world has become a smaller place to live in with increasing convenience of international boundaries getting blurry and globalisation taking the throne. Although, as every coin has two sides, one of the biggest culprits of converting new diseases into pandemics is also, unfortunately globalisation. ${ }^{1}$ Infectious diseases especially of the viral origin spread like wildfire and is considered the most common reason for disruption of livelihood, trades and the overall economy. ${ }^{2}$ Diseases like Ebola, Lassa, Yellow Fever, Zika, Chikungunya, the H1N1 influenza, Middle East Respiratory Syndrome (MERS), SARS, cholera and the ongoing COVID-19 are some of the viral outbreaks that have surfaced into the population in this millennium. ${ }^{3}$

In 1798, the inoculation of humans against the smallpox with cowpox, a less virulent substitute, viral infections were solely controlled by vaccinations and made a majority of first line treatment since, last two centuries. ${ }^{4}$ Even though diagnosis and first-hand treatment are usually symptomatic relief and vaccinations, a rapid growth in the biotechnological arena has introduced the role of genetic manipulation into the treatment of such outbreaks which has made a major impact in the treatment of the diseases. ${ }^{5}$ Genetic manipulation has been emerging as one of the main foundation of techniques in gene therapy and virology to counter diseases and control symptoms. This is done by inserting, deleting or replacing nucleotides for specified locations in the genetic map of the subject. ${ }^{6}$ Gene therapies have actively been used in treatment of viral diseases like influenza and HIV, 7 and many viral interventions have helped in the treatment of other diseases like tuberculosis and malaria in recent times. ${ }^{8}$ Molecular genetic techniques have been growing and evolving based on the mechanism of action of viruses and the gene expressions they affect, along with the basic morphology of the cellular components of the micro-organism. ${ }^{9}$ The techniques have been combined in the given table.

\section{GENE THERAPY IN THE TREATMENT OF VARIOUS EPIDEMICS AND PANDEMICS}

\section{Human Immuno Deficiency Virus}

Acquired Human Immuno Deficiency Syndrome is caused by HIV 1 of the lentivirus family. Discovered in the 1980s, this disease shows very less or mild influenza like signs and symptoms at initial stages which can develop into severe nausea, vomiting and since the disease causes reduction of immune system, diseases like Kaposi sarcoma and tuberculosis are very commonly seen. ${ }^{13}$ Genetic intervention in the treatment of HIV-AIDS has proven to be a paradigm for the field. ${ }^{14}$ Belonging to the lentivirus family, this virus consists of the RNA genome which is reverse transcribed into DNA by reverse transcriptase protein. Theoretically, the viral genome has 3 sets of proteins, which if interrupted or inhibited can disrupt the life cycle of HIV. The treatment options include ${ }^{15}$

a. Development of potent anti-HIV 1 transgenes - which can be injected at any stage to disrupt the replication of the HIV 1 virion which is infective in nature. b. Protein Strategies - include genetically engineered trans dominant negative mutants, intrakine toxins and single chain antibodies to inhibit HIV-1 virion. DNA vaccines are also being developed for the same.

c. RNA Strategies - include use of antisense RNA, ribozymes, RNA decoys and interference RNA commonly called RNAi.

\section{Ebola}

Coming from the family of Filoviridae, Ebolavirus was discovered in 1977 as a severe disease affecting the humans. Many outbreaks have occurred in different parts of the world especially in the sub-Sharan region, most recent being the 2018 outbreak in Democratic Republic of Congo affecting about 29 health zones and is recorded as the largest outbreak since the virus's discovery. ${ }^{16}$ The disease spreads from direct contact, either with the infected or from the objects belonging to the infected individual. Symptoms of the disease progress from dry symptoms namely fever, cough and malaise to considerably wet symptoms like diarrhoea and vomiting that can become fatal if left untreated. With vaccinations being mandatory for the prevention of the spread of the disease, the treatment of the disease has taken an enhanced path in genetic engineering. ${ }^{17}$ Techniques produced to counter Ebola virus include

\section{Reverse Genetics}

This technique consists of development of the filovirus with the key gene sequence, but which isn't recombinant hence, isn't infectious in nature. Similar studies have been done and trials have performed using the Rabies Virus (RABV) which has expressed glycoproteins for both rabies and Ebola, hence, inducing humoral immunity against the two and confer protection of the patient. ${ }^{18}$

\section{Nucleoside Analog Candidate Therapies}

These are safe and effective antiviral agents that are designed and engineered to be used as post exposure treatment.

\section{RNA-Silencing Molecules and Antisense Oligomers}

Also commonly referred to as RNA interfering molecules which are targeted to disrupt the cell differentiation and development of the virus. These are very commonly termed as SiRNA and renamed as TKM Ebola which function to target the polymerase (L) gene of ZEBOV which has successful clinical trials and is used efficiently for treatment. ${ }^{20}$

\section{Immunotherapeutics}

The idea of using passive immunity for treatment of this disease goes as long as 1995 in Zaire, although many trials have been unsuccessful until recent times, where a novel immunotherapeutic, a combination of monoclonal antibodies named (Zmapp) ${ }^{21}$ has gained success in animal trials and is currently undergoing clinical trials in the States.

\section{SARS (Severe Acute Respiratory Syndrome)}

SARS-CoV also called as SARS coronavirus was first reported in 2002 in Southern China which later affected 26 countries, making a mark in the list of pandemics that hit the world in $21^{\text {st }}$ century. It was an airborne disease which is spread person to person. 


\begin{tabular}{|c|c|c|c|}
\hline $\begin{array}{c}\text { Nucleic Acid Based Genetic } \\
\text { Therapy }\end{array}$ & Description & Advantages & Disadvantages \\
\hline 1. Antisense RNA and DNA & $\begin{array}{l}\text { These help to block occurring gene expression by nucleic } \\
\text { acid base pairing (Watson and Crick Model) }\end{array}$ & $\begin{array}{l}\text { These are up taken easily by the host without } \\
\text { any immunologic complication. }\end{array}$ & $\begin{array}{l}\text { Stability of the oligonucleotides } \\
\text { used esp. in antisense DNA still } \\
\text { remains controversial. }\end{array}$ \\
\hline 2. Ribozymes & $\begin{array}{l}\text { These are antisense RNA molecules which also have } \\
\text { catalytic activity present in them, they help in inhibition by } \\
\text { binding to the target cells to undergo a specific } \\
\text { hybridization, cleaving the phosphor-di-ester bond present. }\end{array}$ & $\begin{array}{l}\text { The major advantage is that these are not } \\
\text { consumed during the reaction, hence one } \\
\text { single ribozyme can help inhibit several } \\
\text { molecules }\end{array}$ & $\begin{array}{l}\text { The catalyst activity extent of the } \\
\text { Ribozymes is still unknown. }\end{array}$ \\
\hline 3. RNA Decoys & $\begin{array}{l}\text { These are overexpressed short strands of RNA molecules } \\
\text { which are substitutes for cis-acting elements, acting as } \\
\text { decoys for the trans activating proteins hence preventing } \\
\text { the binding of both in viral genome. }\end{array}$ & $\begin{array}{l}\text { These are rarely affected by any mutation in } \\
\text { the targeted genome and hence be used in } \\
\text { various stages of mutation of the genome. }\end{array}$ & $\begin{array}{l}\text { The over expression of the RNA } \\
\text { transcripts can have deleterious } \\
\text { effects in cell functioning and } \\
\text { harmony. }\end{array}$ \\
\hline \multicolumn{4}{|c|}{ Table 1. Techniques Which Involve Nucleic Acid Components for Genetic Therapy. ${ }^{10,11}$} \\
\hline
\end{tabular}

\begin{tabular}{|c|c|c|c|}
\hline $\begin{array}{c}\text { Protein Based Approaches to Gene } \\
\text { Therapy }\end{array}$ & Description & Advantages & Disadvantages \\
\hline 1. Trans-dominant Negative Proteins & $\begin{array}{c}\text { These are mutant forms of different types of proteins } \\
\text { processed in such a way that they help in inhibiting } \\
\text { the infectious agent }\end{array}$ & $\begin{array}{l}\text { Since these proteins compete for essential } \\
\text { substrate with the target organelle, the } \\
\text { mechanism of inhibition is comparatively easier. }\end{array}$ & $\begin{array}{l}\text { These engineered cells have the } \\
\text { tendency to pose immunogenicity } \\
\text { i.e the immune system response } \\
\text { can cause their own destruction }\end{array}$ \\
\hline 2. Anti-Infectious Cellular Proteins & $\begin{array}{c}\text { These are basically derived from normal cellular } \\
\text { components but show specific gene inhibition } \\
\text { activity }\end{array}$ & $\begin{array}{l}\text { Engineered cells show non-antigenic activity i.e } \\
\text { do not get eliminated by recipient's immune } \\
\text { system. }\end{array}$ & $\begin{array}{l}\text { May have shown success in-vitro } \\
\text { but clinical trials still remain } \\
\text { unsuccessful in case of HIV } \\
\text { treatment }\end{array}$ \\
\hline 3. Single chain Antibodies- & $\begin{array}{l}\text { These are in the form of single chain variable } \\
\text { fragments belonging to an antibody which has the } \\
\text { ability to retain entire antigen specificity and binding } \\
\text { site capability of the parent gene. }\end{array}$ & $\begin{array}{l}\text { These bind to the site and prevent gene function } \\
\text { and cannot be secreted out. }\end{array}$ & Not recorded \\
\hline 4. Suicide Genes- & $\begin{array}{l}\text { These genes are used in order to selectively kill the } \\
\text { infectious cells in the host. }\end{array}$ & - & - \\
\hline \multicolumn{4}{|c|}{ Table 2. Nucleic Acid Based Approaches to Gene Therapy ${ }^{10,12}$} \\
\hline
\end{tabular}

\begin{tabular}{|c|c|c|c|}
\hline Immunotherapy & Description & Advantages & Disadvantages \\
\hline 1. DNA Vaccine & $\begin{array}{l}\text { Generating an immune response against the native } \\
\text { components and proteins of the infectious disease with } \\
\text { the help of transmission of plasmid DNA into the host } \\
\text { cells }\end{array}$ & $\begin{array}{l}\text { i. easy to produce } \\
\text { ii. effective building humoral and cytotoxic } \\
\text { immunity due to presence of native proteins } \\
\text { iii. target cell specificity is not important. }\end{array}$ & $\begin{array}{l}\text { i. chances of affecting other cell types than } \\
\text { targeted. } \\
\text { ii. anti-DNA antibodies that can be } \\
\text { produced } \\
\text { iii. random integration of vaccinated DNA } \\
\text { in target cells }\end{array}$ \\
\hline $\begin{array}{l}\text { 2. Agent-Specific Cytotoxic T } \\
\text { Cells }\end{array}$ & $\begin{array}{l}\text { Ex-vivo expansion of patients own antibodies as a } \\
\text { method of treating the disease }\end{array}$ & - & - \\
\hline
\end{tabular}

\begin{tabular}{|c|c|c|}
\hline Name & Mechanism of Action & Status \\
\hline Favipiravir & $\begin{array}{l}\text { Induce viral mutagenesis hence reducing post } \\
\text { exposure symptom severity. }\end{array}$ & Approved for use \\
\hline JK-05 & $\begin{array}{l}\text { An antiviral compound designed to target RNA } \\
\text { polymerase inhibiting viral replication. }\end{array}$ & $\begin{array}{l}\text { Approved for } \\
\text { emergency use only }\end{array}$ \\
\hline BCX440 & $\begin{array}{l}\text { An adenosine analog which inhibits the } \\
\text { function of viral RNA polymerase }\end{array}$ & Not approved \\
\hline \multicolumn{3}{|c|}{$\begin{array}{l}\text { Table 4. Nucleoside Analog Candidates Used in Therapeutic } \\
\text { Advancements Taken Against Ebola. }{ }^{19}\end{array}$} \\
\hline
\end{tabular}

Symptoms include fever, malaise, myalgia, diarrhoea which mimic flu like symptoms mostly. Vaccinations have not been developed yet but some genetic therapy has taken place to provide treatment and prevention of the spread of the virus. ${ }^{22}$ Currently, many studies are undergoing which use SiRNA duplexes (RNA interference genome) as an efficient prophylactic agent due to its antiviral efficacy and a comparatively lower therapeutic effect, but counter measures have produced alongside to increase the therapeutic properties too. ${ }^{23}$

\section{H1N1 Swine Flu (Influenza A)}

A disease caused by the A type virus of the Orthomyxoviridae family, H1N1 influenza broke out to become one of the documented pandemics in 2009, attacking around 5 - $10 \%$ adults and almost 20 - $30 \%$ children. ${ }^{24}$ With flu like symptoms, this disease is transmitted via droplets from unprotected cough and sneezes and is usually seen spreading in crowded places. Although the infected individuals range from asymptomatic to mild symptomatic, the fatal complications of this disease include pneumonitis, otitis media and bacterial pneumonia. ${ }^{25}$ As the virus contains high affinity towards mutation, targeted or specific gene sequencing seems tedious and ineffective in the case. Currently, neuraminidase inhibitors (NAIs) like oseltamivir, zanamivir and peramivir are widely used to treat $\mathrm{H} 1 \mathrm{~N} 1 .^{26}$

Genetic therapies are available in the form of manipulating HA and NA functionality. MHAA4549A, MEDI8852, VIS-410, JNJ63623872, Favipiravir and JJ3297 are therapies approved which work by manipulating the functionality of HA and NA, hence, countering to the mutations and increasing the efficacy of the treatment. ${ }^{27}$

\section{COVID - 19}

Originated in Wuhan, China in the year 2019, COVID-19 disease is caused by a new specimen of the coronavirus family named as SARS-Cov2. This virus has caused an international havoc with the ongoing outbreak and one of the largest pandemics recorded till date in this millennium covering almost 180 countries. ${ }^{28}$ The symptoms include fever, malaise, and dry cough. Severe cases if left undiagnosed can advance into pneumonia which might turn fatal. ${ }^{29}$ There is currently no treatment found, neither therapeutic, nor prophylactic, many combination drugs are coming to relieve symptoms but none of them have become the first line treatment of the disease. Genetic considerations taken for the treatment of the disease 
work around the immune response of the body to the virus, where studies are being done on-

a. Innate Immune Response - For catering an anti-viral response the innate immune cells have to follow the pathogenic associated molecular pattern (PAMPs) upon the invasion of virus which is recognised by the endosomal RNA receptors followed by the downstream signalling cascade hence, activating the first line defence mechanism of the body to fight the virus. ${ }^{30}$

b. Adaptive Immune Response (for vaccine development) The Th1 immune response is playing a very important role in the control of SRAS-CoV virus. The CD8 $+\mathrm{T}$ cell response is one of the major reasons to not make the viral infection exceed up to a lung pathology. This information will be useful while developing passive immunisation for the disease. ${ }^{31}$

\section{PROSPECTS AND PROBLEMS IN GENE THERAPY}

The rationale of gene therapy in treatment of viral outbreaks is that most of the genes that are tailored to enhance the function of immune response of the body. These genomes, nucleotides or proteins made reduce efficacy of the viral antigen by either inhibiting or disrupting its life cycle to relieve the symptoms caused in the human body. ${ }^{32,33}$

Mostly the genomes are used as a therapeutic measure but due to increasing outbreaks of the diseases, prophylactic and preventive measures have also been emerging which include such genetic advances. But with every good intention there are some side effects attached to it, especially when genes are involved. Gene therapy is a young field, so with every study involved there are more failures than successes involved. Studies are time consuming, technique sensitive and do not have any guarantee to provide positive results. But with the new techniques emerging, competition rising, gene therapy holds potential to become the treatment of choice in the new millennium. ${ }^{34}$

\section{CONCLUSIONS}

Emerging viral pandemics around the world have given rise to the introduction of genetic manipulations in the field of virology. From adding, deleting and replacing the genes, treatment options have been advanced for diseases like HIVAIDS, SARS, Swine Flu and even the ongoing pandemic of COVID-19. The field being new, it still holds a lot of unexplored arenas which might prove to become fruitful for the mankind and change the paradigm of treatment.

Financial or other competing interests: None.

Disclosure forms provided by the authors are available with the full text of this article at jemds.com.

\section{REFERENCES}

[1] Moghadas SM, Pizzi NJ, Wu J, et al. Managing public health crises: the role of models in pandemic preparedness. Influenza Other Respir Viruses 2009;3(2):75-9.

[2] World Health Organization. Managing epidemics: key facts about major deadly diseases. World Health Organization 2018: p. 255.

[3] Hughes JM, Pike BL, Saylors KE, et al. The origin and prevention of pandemics. Clin Infect Dis 2010;50(12):1636-40.

[4] Cohen J. Bioterrorism. Smallpox vaccinations: how much protection remains? Science 2001;294(5544):985.

[5] Howard HC, van El CG, Forzano F, et al. One small edit for humans, one giant edit for humankind? Points and questions to consider for a responsible way forward for gene editing in humans. Euro J Hum Genet 2018;26(1):111.

[6] ACMG Board of Directors. Genome editing in clinical genetics: points to consider - a statement of the American College of Medical Genetics and Genomics. Genet Med 2017;19(7):723-4.

[7] Savarino A. Expanding the frontiers of existing antiviral drugs: possible effects of HIV-1 protease inhibitors against SARS and avian influenza. J Clin Virol 2005;34(3):170-8.

[8] McNicholl JM, Downer MV, Udhayakumar V, et al. Hostpathogen interactions in emerging and re-emerging infectious diseases: a genomic perspective of tuberculosis, malaria, human immunodeficiency virus infection, hepatitis B and cholera. Annu Rev Public Health 2000;21:15-46.

[9] Dickler HB, Collier E. Gene therapy in the treatment of disease. Journal of Allergy and Clinical Immunology 1994;94(6):942-51.

[10] Bunnell BA, Morgan RA. Gene therapy for infectious diseases. Clin Microbiol Rev 1998;11(1):42-56.

[11] Aguilar-Cordova E, Chinen J, Donehower LA, et al. Inhibition of HIV-1 by a double transdominant fusion gene. Gene Ther 1995;2(3):181-6.

[12] Anderson WF. Human gene therapy: why draw a line? J Med Philos 1989;14(6):681-93.

[13] Piot P, Bartos M, Ghys PD, et al. The global impact of HIV/AIDS. Nature 2001;410(6831):968-73.

[14] Maciejewski JP, Weichold FF, Young NS, et al. Intracellular expression of antibody fragments directed against HIV reverse transcriptase prevents HIV infection in vitro. Nat Med 1995;1(7):667-73.

[15] Yu M, Poeschla E, Wong-Staal F. Progress towards gene therapy for HIV infection. Gene Ther 1994;1(1):13-26.

[16] Dixon MG, Schafer IJ. Ebola viral disease outbreak - West Africa, 2014. Morbidity and Mortality Weekly Report 2014;63(25):548-51.

[17] Xu L, Sanchez A, Yang Z, et al. Immunization for ebola virus infection. Nat Med 1998;4(1):37-42.

[18] Uebelhoer LS, Albariño CG, McMullan LK, et al. Highthroughput, luciferase-based reverse genetics systems for identifying inhibitors of Marburg and Ebola viruses. Antiviral Res 2014;106:86-94.

[19] Kilgore PE, Grabenstein JD, Salim AM, et al. Treatment of ebola virus disease. Pharmacotherapy 2015;35(1):43-53. 
[20] Walker LM, Burton DR. Passive immunotherapy of viral infections:'super-antibodies' enter the fray. Nature Reviews Immunology 2018;18(5):297-308.

[21] Qiu X, Wong G, Audet J, et al. Reversion of advanced ebola virus disease in nonhuman primates with ZMapp. Nature 2014;514(7520):47-53.

[22] Holmes KV. SARS coronavirus: a new challenge for prevention and therapy. J Clin Invest 2003;111(11):16059.

[23] Li BJ, Tang Q, Cheng D, et al. Using siRNA in prophylactic and therapeutic regimens against SARS coronavirus in rhesus macaque. Nat Med 2005;11(9):944-51.

[24] Dawood FS, Jain S, Finelli L, et al. Emergence of a novel swine-origin influenza A (H1N1) virus in humans. N Engl J Med 2009;360(25):2605-15.

[25] Lee CS, Lee JH. Dynamics of clinical symptoms in patients with pandemic influenza A (H1N1). Clin Microbiol Infect 2010;16(4):389-90.

[26] Dao TT, Nguyen PH, Lee HS, et al. Chalcones as novel influenza A (H1N1) neuraminidase inhibitors from glycyrrhiza inflata. Bioorg Med Chem Lett 2011;21(1):294-8.
[27] Khurana S, Verma S, Verma N, et al. Properly folded bacterially expressed H1N1 hemagglutinin globular head and ectodomain vaccines protect ferrets against H1N1 pandemic influenza virus. PloS One 2010;5(7):e11548.

[28] Roser M, Ritchie H, Ortiz-Ospina E. Coronavirus disease (COVID-19) - statistics and research. Our World in Data 2020.

[29] Rothan HA, Byrareddy SN. The epidemiology and pathogenesis of coronavirus disease (COVID-19) outbreak. J Autoimmun 2020;109:102433.

[30] Prompetchara E, Ketloy C, Palaga T. Immune responses in COVID-19 and potential vaccines: lessons learned from SARS and MERS epidemic. Asian Pac J Allergy Immunol 2020;38(1):1-9.

[31] Shi Y, Wang Y, Shao C, et al. COVID-19 infection: the perspectives on immune responses. Cell Death Differ 2020;27(5):1451-4.

[32] Anderson WF. Prospects for human gene therapy. Science 1984;226(4673):401-9.

[33] Gorecki DC. Prospects and problems of gene therapy: an update. Expert Opin Emerg Drugs 2001;6(2):187-98.

[34] Pfeifer A, Verma IM. Gene therapy: promises and problems. Annu Rev Genomics Hum Genet 2001;2(1):177-211. 